\title{
Preparation and Physical Properties of $\mathrm{Tl}_{0.65} \mathrm{Hg}_{0.35} \mathrm{Ba}_{2} \mathrm{Ca}_{\mathrm{n}-1} \mathrm{Cu}_{\mathrm{n}} \mathrm{O}_{2 \mathrm{n}+3-\delta}(n=1,2,3)$ Superconductors
}

\author{
Kareem Ali Jasim ${ }^{1}$ \\ ${ }^{1}$ College of Education for Pure Science Ibn-Al-Haitham, Department of Physics, University of Baghdad, Iraq \\ Correspondence: Kareem Ali Jasim, College of Education for Pure Science Ibn-Al-Haitham Department of \\ Physics, University of Baghdad, Iraq. E-mail: kaj_kaj6@yahoo.com,kaj_1964@yahoo.com
}

Received: January 8, 2013 Accepted: February 19, 2013 Online Published: July 15, 2013

doi:10.5539/apr.v5n4p80 URL: http://dx.doi.org/10.5539/apr.v5n4p80

\begin{abstract}
Multilayered cuprates of $\mathrm{Tl}_{0.65} \mathrm{Hg}_{0.35} \mathrm{Ba}_{2} \mathrm{Ca}_{\mathrm{n}-1} \mathrm{Cu}_{\mathrm{n}} \mathrm{O}_{2 \mathrm{n}+3-\delta}$, with $\mathrm{n}=1-3$ have been synthesized by using solid state reaction method in order to investigate the variation of transition temperature $\mathrm{T}_{\mathrm{c}}$. The temperature dependence of resistivity showed that the $T_{\mathrm{c}}$ depends on $\mathrm{n}$. The $c$-lattice constants of the observed phases obey, the $c$-axis rule of $c=3.117 \mathrm{n}+6.5467$ for Tl-O layer structures. With an increase in $\mathrm{Cu}-\mathrm{O}$ layers, the superconducting transition temperature is determined by electrical resistivity-temperature dependency and rises reaching a maximum value of $121 \mathrm{~K}$ at $n=3$.
\end{abstract}

Keywords: superconducting transition temperature $\mathrm{T}_{\mathfrak{c}}$, electrical resistivity, lattice constants, layer structures.

\section{Introduction}

Perovskite-related oxides were identified in $\mathrm{Tl}-\mathrm{Ba}-\mathrm{Ca}-\mathrm{Cu}-\mathrm{O}$ system, which forms the homologous series which are represented by general formula $\mathrm{TlBa}_{2} \mathrm{Ca}_{\mathrm{n}-1} \mathrm{Cu}_{n} \mathrm{O}_{2 n+3-\delta}$ ( $\mathrm{n}$ : is the number of consecutive $\mathrm{Cu}-\mathrm{O}$ layers). Superconductivity in $\mathrm{TlBa}_{2} \mathrm{Ca}_{n-1} \mathrm{Cu}_{n} \mathrm{O}_{2 n+3-\delta}$ is believed to originate from the presence of holes in $\mathrm{CuO}_{2}$ planes (Sheng \& Hermann, 1988a), while Tl-O-layers serve as reservoir of charge carriers. The crystal structures of first three phases ( $\mathrm{n}=1,2$ and 3$)$ have primitive tetragonal cells at room temperature. These phases are referred to as Tl:1201, Tl:1212, and Tl:1223, which are formed by the conventional sintering method (Sheng \& Hermann, 1988b; Sheng et al., 1988; Ganguli, Subbanna, \& Rao, 1988; Morosin, Ginlev, Schirber, \& Venturini, 1988). In the case of strict stoichiometry, a formal oxidation state of $\mathrm{Cu}$ in the $\mathrm{TlBa}_{2} \mathrm{Ca}_{\mathrm{n}-1} \mathrm{Cu}_{\mathrm{n}} \mathrm{O}_{2 \mathrm{n}+3-\delta}$ series varies from $\mathrm{Cu}^{3+}$ to $\mathrm{Cu}^{2.2+}$ upon $\mathrm{n}$ change from 1 to 3 . Thermogravimetry and chemical analysis show that these homologous phases are often intergrown to each other (Kareem, Muhammed, \& Mostafa, 2009; Yildirim, Bal, \& Varilci, 2012). In other words, it is difficult to prepare any of these as a complete monophase. This is particularly the same as the case of the 1223 phase. It is known by now that partial replacement of $\mathrm{Tl}^{+2}$ in an oxygen deficient Tl- $\mathrm{O}_{\delta}$ layer is happened by cations which have higher oxidation states than $\mathrm{Pb}^{+4}, \mathrm{Bi}^{+3}, \mathrm{Hg}^{+2}$ in order to improve the stability and to make the synthesis of single phase material readily feasible. Stabilizing the superconductive phase may also increase the superconducting transition temperature and finally can introduce more oxygen in the crystal structures (Kaneko, Wada, Yamauchi, \& Tanaka, 1990; Morgan, Doi, \& Nelson, 1993; Kim et al., 2007; Asthana \& Srivastava, 2001). We present our studies by the synthesis of the $\mathrm{TlBa}_{2} \mathrm{Ca}_{n-1} \mathrm{Cu}_{n} \mathrm{O}_{2 n+3-\delta}(\mathrm{n}=1-3)$ phases by substituting an amount of mercury $(\mathrm{Hg})$ with Thallium that exploits the very good control of the reaction which is achieved with a low $\mathrm{O}_{2}$ pressure and permits the formation of $\mathrm{Tl}_{0.65} \mathrm{Hg}_{0.35} \mathrm{Ba}_{2} \mathrm{Ca}_{\mathrm{n}-1} \mathrm{Cu}_{\mathrm{n}} \mathrm{O}_{2 \mathrm{n}+3-\delta}$ Superconductors.

\section{Experimental}

The solid state reaction method was employed to prepare polycrystalline samples with nominal starting composition $\mathrm{Tl}_{0.65} \mathrm{Hg}_{0.35} \mathrm{Ba}_{2} \mathrm{Ca}_{\mathrm{n}-1} \mathrm{Cu}_{\mathrm{n}} \mathrm{O}_{2 \mathrm{n}+3-\delta}$ with $\mathrm{n}=1$, 2 and 3. High purity oxides (99.99\%) of $\mathrm{BaCO}_{3}, \mathrm{CaCO}_{3}$ and $\mathrm{CuO}$ were mixed in appropriate amounts and were heated at $820^{\circ} \mathrm{C}$ for over 8 hours with several intermittent grindings. The heated precursor was then mixed completely with appropriate amounts of $\mathrm{Tl}_{2} \mathrm{O}_{3}, \mathrm{HgO}$, and was then pressed into pellets of $15 \mathrm{~mm}$ diameter and $3 \mathrm{~mm}$ thickness. The pellets were heated at $860{ }^{\circ} \mathrm{C}$ in flowing $\mathrm{O}_{2}$ followed by over 20 hours and cooled at the room temperature. The samples were characterized by powder X-ray diffraction (XRD) method by using X-ray diffractometer type (Philips) and have the following features, the source $\mathrm{Cu}_{\mathrm{k} \alpha}$ current $(20 \mathrm{~mA})$, voltage $(40 \mathrm{KV})$ and $\lambda=1.5405 \mathrm{~A}^{0}$. The lattice parameters a and $\mathrm{c}$ were calculated by using a computer program based on Cohen's least square method (Manivannan, Gopalarishnan, \& Rao, 1994). 
The $\rho-T$ (resistivity vs. temperature) characteristics of these samples were measured by means of a standard d.c four-probe technique to investigate their superconducting state. The excess of oxygen content $(\delta)$ as well as for measuring the critical temperatures was described elsewhere (Kareem \& Alwan, 2009). The scanning electron micrographs were recorded by using a Philips XL 30 Scanning Electron Microscope (SEM).

\section{Results and Discussion}

The structures of $\mathrm{Tl}_{0.65} \mathrm{Hg}_{0.35} \mathrm{Ba}_{2} \mathrm{Ca}_{\mathrm{n}-1} \mathrm{Cu}_{\mathrm{n}} \mathrm{O}_{2 \mathrm{n}+3-\delta}$, with $\mathrm{n}=1-3$ phases were well established by X-ray diffraction analyses. Figure 1 shows the powder X-ray diffraction patterns of 1201, 1212, and 1223 phases which were prepared in our laboratory. The positions and intensities of the diffraction peaks reveal that our samples mainly consist of a major 1201, 1212 and 1223 phase and a small amount of a minor unidentified. The lattice parameters of 1201, 1212 and 1223 phases were calculated by using the d-values and (hkl) reflections of the observed x-ray diffraction pattern through the software program based on Cohen's least square method. The obtained parameters $\mathrm{a}, \mathrm{b}, \mathrm{c}$ and the ratio $\mathrm{c} / \mathrm{a}$, show tetragonal symmetry structure for all our samples. The c-axis lattice constant and cla ratio increase with the increase of $\mathrm{Cu}-\mathrm{O}$ layers; the unit cell is made up of alternating arrays from one to three $\mathrm{Cu}-\mathrm{O}$ layers. From Figure 2 ,it was found from that the increase in $n$ claim leads to an increase in the length of $c$-lattice parameter as a result of the introduction of $\mathrm{Cu}-\mathrm{O}$ and $\mathrm{Ca}-\mathrm{O}$ layers inside the structure of 1201 phase to produce 1212 and 1223 phases. The $c$-lattice parameter of the observed phases obeys, the $c$-axis rule of $c=3.117 \mathrm{n}+6.5467$ for $\mathrm{Tl}_{0.65} \mathrm{Hg}_{0.35} \mathrm{Ba}_{2} \mathrm{Ca}_{\mathrm{n}-1} \mathrm{Cu}_{\mathrm{n}} \mathrm{O}_{2 \mathrm{n}+3-\delta}$ layer structures. Table 1 summarizes the lattice parameters, oxygen content $(\delta)$, Mass density, critical temperature onset " $T_{c \text { (onset) }}$ ", zero resistivity temperature offset " $T_{c(\text { offset })}$ and transition width $\Delta \mathrm{T}$ " of the 1201,1212 , and 1223 thallium copper oxides.

Table 1. Values of transition temperature $\mathrm{T}_{\mathrm{c}(\text { offset) }}, \mathrm{T}_{\mathrm{c} \text { (onset) }}$, oxygen content $(\delta)$ and lattice parameters for $\mathrm{Tl}_{0.65} \mathrm{Hg}_{0.35} \mathrm{Ba}_{2} \mathrm{Ca}_{\mathrm{n}-1} \mathrm{Cu}_{\mathrm{n}} \mathrm{O}_{2 \mathrm{n}+3-\delta}$, with $\mathrm{n}=1,2$, and 3

\begin{tabular}{|c|c|c|c|c|c|c|c|c|c|}
\hline$n$ & Samples & $\begin{array}{l}T_{\mathrm{c}(\mathrm{Offset})} \\
(\mathrm{K})\end{array}$ & $\begin{array}{l}\mathrm{T}_{\mathrm{c} \text { (onset) }} \\
\text { (K) }\end{array}$ & $\Delta \mathrm{T}$ & $\delta\left(o_{2}\right)$ & $a\left(\mathrm{~A}^{0}\right)$ & $c\left(\mathrm{~A}^{0}\right)$ & $c / a$ & $\begin{array}{l}\text { Mass density } \\
\left(\mathrm{g} / \mathrm{cm}^{3}\right)\end{array}$ \\
\hline 1 & $\mathrm{Tl}_{0.65} \mathrm{Hg}_{0.35} \mathrm{Ba}_{2} \mathrm{Cu}_{1} \mathrm{O}_{4.911}$ & 87 & 132 & 23 & 0.089 & 3.892 & 9.693 & 2.490 & 5.35 \\
\hline 2 & $\mathrm{Tl}_{0.65} \mathrm{Hg}_{0.35} \mathrm{Ba}_{2} \mathrm{CaCu}_{2} \mathrm{O}_{6.884}$ & 97 & 121 & 17 & 0.116 & 3.848 & 12.722 & 3.306 & 5.67 \\
\hline 3 & $\mathrm{Tl}_{0.65} \mathrm{Hg}_{0.35} \mathrm{Ba}_{2} \mathrm{Ca}_{2} \mathrm{Cu}_{3} \mathrm{O}_{8.763}$ & 115 & 112 & 12 & 0.237 & 3.841 & 15.927 & 4.146 & 5.89 \\
\hline
\end{tabular}




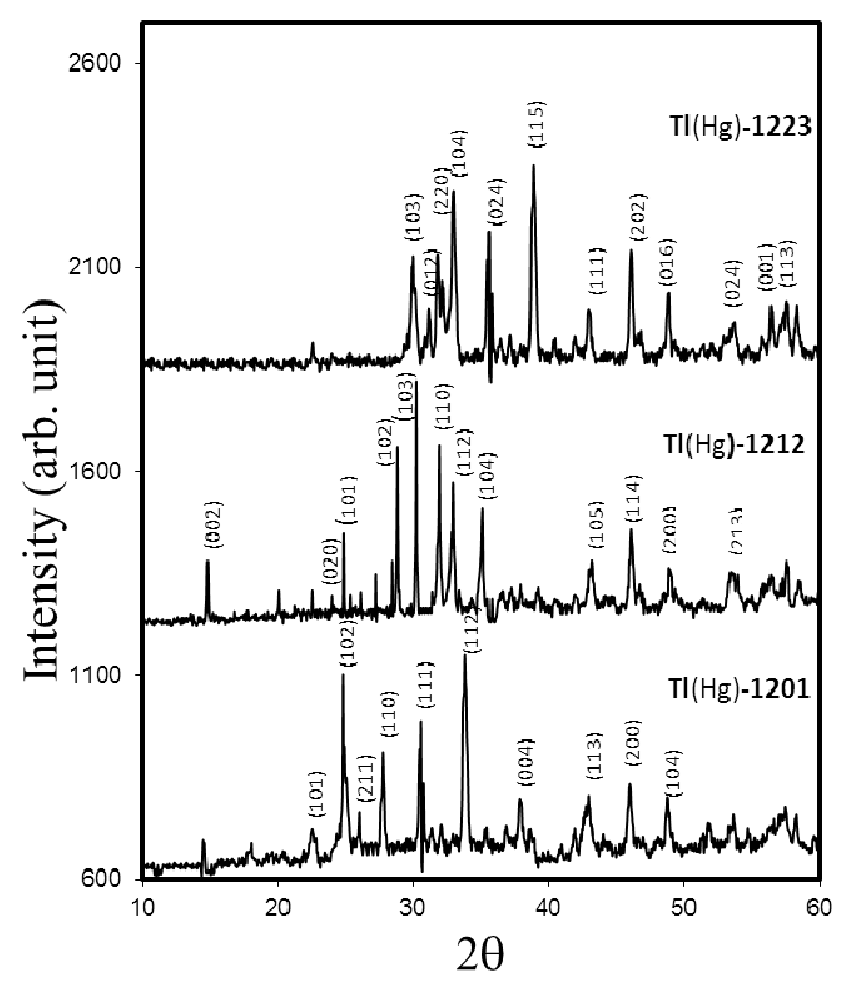

Figure 1. XRD patterns of the $\mathrm{Tl}_{0.65} \mathrm{Hg}_{0.35} \mathrm{Ba}_{2} \mathrm{Ca}_{\mathrm{n}-1} \mathrm{Cu}_{\mathrm{n}} \mathrm{O}_{2 \mathrm{n}+3-\delta}$, with $\mathrm{n}=1,2$ and 3

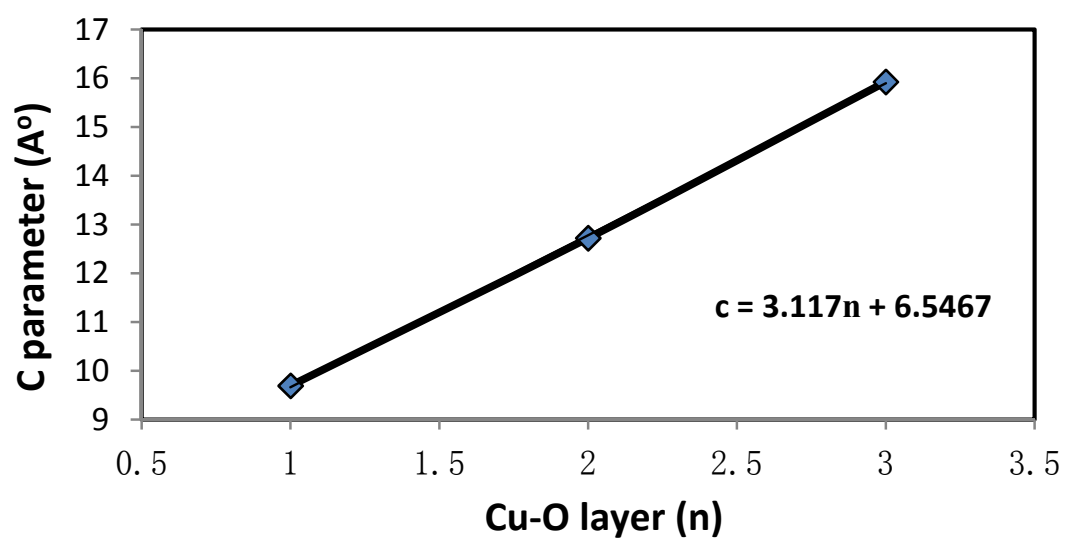

Figure 2 Lattice parameter $\mathrm{c}$ as a function of $\mathrm{Cu}-\mathrm{O}$ layer

Figure 3 displays the temperature dependence of the normalized resistivity $\rho$ for $\mathrm{Tl}_{0.65} \mathrm{Hg}_{0.35} \mathrm{Ba}_{2} \mathrm{Ca}_{\mathrm{n}-1} \mathrm{Cu}_{\mathrm{n}} \mathrm{O}_{2 \mathrm{n}+3-\delta}$, with $\mathrm{n}=1-3$ phases. All samples are characterized by a metallic behavior form room temperature down to $200 \mathrm{~K}$. Basically, the normal metallic behavior reflects the conduction along the $\mathrm{CuO}$ planes. The values of critical transition temperature at zero resistivity temperature $T_{c(\text { offset) }}$ and on set $T_{c \text { (onset) }}$ for grown $\mathrm{Tl}_{0.65} \mathrm{Hg}_{0.35} \mathrm{Ba}_{2} \mathrm{Ca}_{\mathrm{n}-1} \mathrm{Cu}_{\mathrm{n}} \mathrm{O}_{2 \mathrm{n}+3-\delta}$, with $\mathrm{n}=1-3$ phases are $87,97,115 \mathrm{~K}$ and $117,123,131 \mathrm{~K}$ respectively. It is clear that the increase of the $\mathrm{Cu}-\mathrm{O}$ layers which leads to increase the holes in the structures thus enhanced the transition temperature from $87 \mathrm{~K}$ to $115 \mathrm{~K}$ and reduced the transition width $\Delta \mathrm{T}$ as shown in Table 1. 


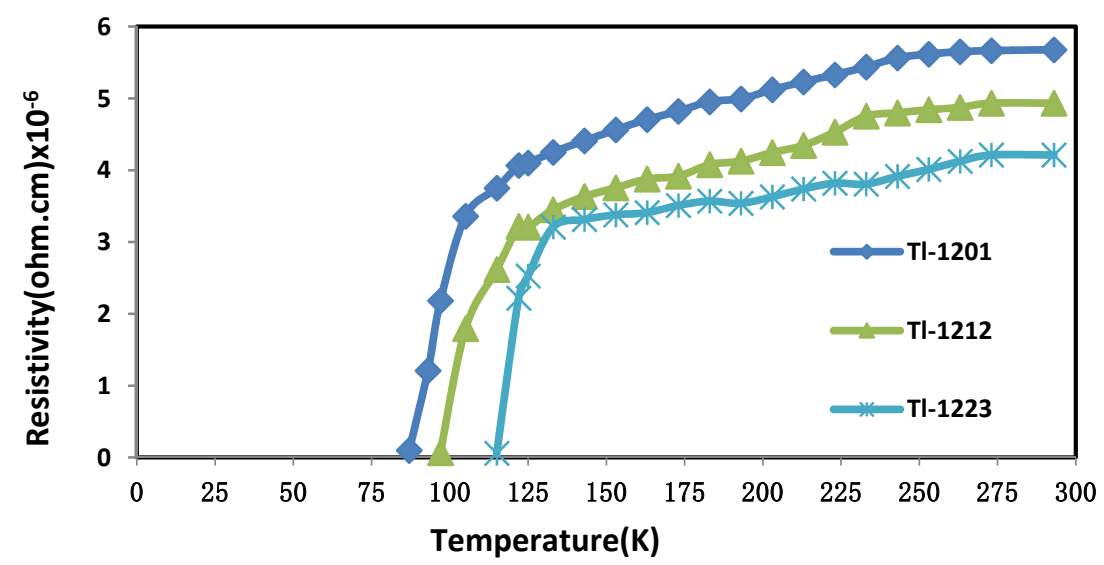

Figure 3. Resistivity versus temperature for $\mathrm{Tl}_{0.65} \mathrm{Hg}_{0.35} \mathrm{Ba}_{2} \mathrm{Ca}_{\mathrm{n}-1} \mathrm{Cu}_{\mathrm{n}} \mathrm{O}_{2 \mathrm{n}+3-\delta}$, with $\mathrm{n}=1-3$ phases

Figure 4 shows SEM micrographs which are taken with secondary electrons for the $\mathrm{Tl}_{0.65} \mathrm{Hg}_{0.35} \mathrm{Ba}_{2} \mathrm{Ca}_{\mathrm{n}-1} \mathrm{Cu}_{\mathrm{n}} \mathrm{O}_{2 \mathrm{n}+3-\delta}$ phases, with $\mathrm{n}=1,2$, and 3, samples $\mathrm{A}, \mathrm{B}$, and $\mathrm{C}$ respectively, It is found that the various $\mathrm{Cu}-\mathrm{O}$ layers lead to various grain sizes .This figure shows the formation of three phases which are characterized by thin elongated grains with no preferred orientation within the limit of SEM magnification. 1223-phase specimen had larger grains as compared with those of the 1201 and 1212, due to the increase of the contact areas which leads to a larger density, as shown in Table 1.

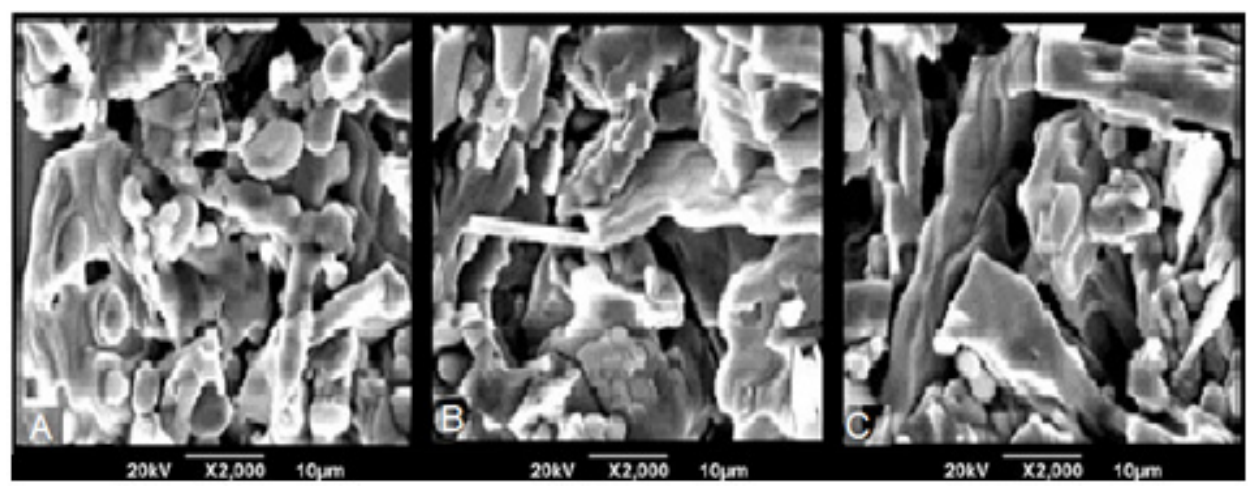

Figure 4. SEM micrographs taken with secondary electrons for the $\mathrm{Tl}_{0.65} \mathrm{Hg}_{0.35} \mathrm{Ba}_{2} \mathrm{Ca}_{\mathrm{n}-1} \mathrm{Cu}_{\mathrm{n}} \mathrm{O}_{2 \mathrm{n}+3-\delta}$, with $\mathrm{n}=1-3$ samples A, B and C respectively

\section{Conclusions}

Three samples of $\mathrm{Tl}_{0.65} \mathrm{Hg}_{0.35} \mathrm{Ba}_{2} \mathrm{Ca}_{\mathrm{n}-1} \mathrm{Cu}_{\mathrm{n}} \mathrm{O}_{2 \mathrm{n}+3-\delta}$, with $\mathrm{n}=1-3$ were synthesized by solid state reaction method. By increasing $\mathrm{n}$, the transition temperature is increased. XRD analysis shows a tetragonal structure for all our samples. The increase of $\mathrm{Cu}-\mathrm{O}$ layers produced an increase in the $\mathrm{c}$-axis lattice constant and the ratio of lattice parameters c/a.

\section{References}

Asthana, A., \& Srivastava, O. N. (2001). Observation of curious spiral growth features in $\mathrm{Tl}$ doped $\mathrm{Hg}$ bearing high temperature superconducting tapes. Bull. Mater. Sci, 24(6), 595-601. http://dx.doi.org/10.1007/BF02704007

Ganguli, A. K., Subbanna, G. N., \& Rao, C. N. R. (1988). $\mathrm{TlCaBa}_{2} \mathrm{Cu}_{2} \mathrm{O}_{7}$ : The 1122 (90 K) superconductor in the new $\mathrm{Tl}(\mathrm{Ca}, \mathrm{Ba})_{n+1} \mathrm{Cu}_{n} \mathrm{O}_{2 n+3}$ series. Physica C, 156, 116. http://dx.doi.org/10.1016/0921-4534(88)90115-3 
Kareem, A. Jasim, \& Alwan, T. J. (2009). The Effect of Simultaneous Substitution of Strontium at the Barium site of $\mathrm{Tl}_{0.6} \mathrm{~Pb}_{0.4} \mathrm{Ba}_{2-\mathbf{x}} \mathrm{Sr}_{\mathbf{x}} \mathrm{Ca}_{2} \mathrm{Cu}_{3} \mathrm{O}_{9-\boldsymbol{\delta}}$ Superconductors. Journal of Superconductivity and Novel Magnetism, 22(8), 861-865. http://dx.doi.org/10.1007/s10948-009-0512-7

Kaneko, T., Wada, T., Yamauchi, H., \& Tanaka, S. (1990). (Tl, Pb, Bi) $\mathrm{Sr}_{2} \mathrm{Ca}_{2} \mathrm{Cu}_{3} \mathrm{O}_{\mathbf{z}}$ superconductors with zero resistance at $120 \mathrm{~K}$. Appl. Phys. Lett., 56(13), 1281-1283. http://dx.doi.org/10.1063/1.103174

Kareem, A. Jasim, Muhammed, A.-N., \& Mostafa, M. A. (2009). Ibn Al-Haitham J. V., 23, 58.

Kim, Y. H., Jeong, D. Y., Chung, U. Ch., Park, H., Chun, H. H., \& Chung, W. S. (2007). J. Ind. Eng. Chem., 13(2), 279-286.

Manivannan, V., Gopalarishnan, J., \& Rao, C. N. R. (1994). Journal of Sold State Chemistry, 109, 205-209.

Morgan, P. E. D., Doi, T. J., \& Nelson, J. G. (1993). Indexed experimental X-ray powder diffraction patterns of $\mathrm{Tl}_{0.5} \mathrm{~Pb}_{0.5} \mathrm{Sr}_{2} \mathrm{Ca}_{2} \mathrm{Cu}_{3} \mathrm{O}_{\mathrm{x}}$ (Tl,Pb-1223) and $\mathrm{TlSr}_{2} \mathrm{Ca}_{2} \mathrm{Cu}_{3} \mathrm{O}_{\mathrm{x}}$ (Tl-1223). Powd. Diff., 8, 194-197. http://dx.doi.org/10.1017/S0885715600018182

Morosin, B., Ginlev, D. S., Schirber, J. E., \& Venturini, E. L. (1988). Crystal structure of $\mathrm{TlCa}_{2} \mathrm{Ba}_{2} \mathrm{Cu}_{3} \mathrm{O}_{9}$. Physica C, 156, 587. http://dx.doi.org/10.1016/0921-4534(88)90026-3

Sheng Z. Z., \& Hermann, A. M. (1988a). Superconductivity in the rare-earth-free Tl-Ba-Cu-O system above liquid-nitrogen temperature. Nature, 332, 55. http://dx.doi.org/10.1038/332055a0

Sheng Z. Z., \& Hermann, A. M. (1988b). Bulk superconductivity at $120 \mathrm{~K}$ in the $\mathrm{Tl}-\mathrm{Ca} / \mathrm{Ba}-\mathrm{Cu}-\mathrm{O}$ system. Nature, 332, 138. http://dx.doi.org/10.1038/332138a0

Sheng Z. Z., Hermann, A. M., Almason, C., Estrada, J., Datta, T., \& Matson, R. (1988). J. Phys. Rev. B, 60, 937.

Yildirim, G., Bal, S., \& Varilci, A. (2012). Effect of Annealing Time and Temperature on Microstructural and Superconducting Properties of $(\mathrm{Bi}, \mathrm{Pb})-2212$ Thin Films Produced by Magnetron Reactive Sputtering. Journal of Superconductivity and Novel Magnetism, 25, 1655-1663. http://dx.doi.org/10.1007/s10948-012-1496-2

\section{Copyrights}

Copyright for this article is retained by the author(s), with first publication rights granted to the journal.

This is an open-access article distributed under the terms and conditions of the Creative Commons Attribution license (http://creativecommons.org/licenses/by/3.0/). 